\title{
CORPUS OF TITLE UNITS OF RUSSIAN-FOREIGN LANGUAGE REFERENCE BOOKS
}

\author{
Li Junying ${ }^{1}$ \\ Rezeda N. Karimullina² \\ Gao Rongguo ${ }^{3}$
}

Abstract: The object of research is linguistic informativity of the macrostructure of language reference books. The research material is bilingual (Russian-Tatar and Russian-Chinese) dictionaries of various types of the end of the $20^{\text {th }}-$ beginning of the $21^{\text {st }} \mathrm{cc}$. The paper presents the classification including various features of the existing bilingual dictionaries. Bilingual linguography comprises various types of anguage reference books. Most of the language reference books analyzed in this paper are monoscopal, with one source language and one target language. One of the key notions of linguography, as well as the essential component of a language reference book, is the vocabulary. One has to admit that in the modern linguography there is still no distinct objective criterion for selecting words for a language reference book.
When composing a vocabulary, subjective factors play a great role. When researching the Russian-foreign language reference books, we revealed a number of mistakes and drawbacks referring to the vocabulary: a) unjustified inclusion of units into the vocabulary, b) unjustified absence of units in the vocabulary, c) orthographic mistakes, d) incorrect use of illustrative material (pictures, photos, etc.). There is no single established opinion as to what information a learner's dictionary should include. It is important to remember that inclusion of specific information depends on the dictionary's addressee and purpose.

Keywords: bilingual linguography, vocabulary, dictionary, macrostructure, Russian language

\footnotetext{
${ }^{1}$ Kazan Federal University (Kazan, Russia)

${ }^{2}$ Kazan Federal University (Kazan, Russia)

${ }^{3}$ Hunan Normal University (Changsha, China). e-mail: re ka@mail.ru. tel.: +7-9053-770541
} 


\section{Introduction}

In the epoch of active introduction of information technologies into scientific research, the role of dictionary compilation is hard to overestimate. A dictionary helps to comprehend the cultural heritage of a nation. One may say that all knowledge accumulated by the humanity are transformed into a dictionary form.

For centuries, dictionary compilation had purely applied, auxiliary character, but, with the increase of newsworthy events, the necessity occurred to develop a theoretical basis of dictionary description. Thus, theoretical linguography appeared, which until now solves the issues of typology of language reference books, their macro- and microstructure. Linguography is a branch of linguistics studying the theory and practice of compiling language reference books (dictionaries); the subdivisions of linguography are lexicography, phraseography, morphemography, etc. [1: 4-9].

The issues of modern linguography were studied in the works by V.P. Berkov, V.V. Dubichinskiy,
V.V. Morkovkin, M. Klotz, Th. Herbst, L. Zgusta and many others.

One of the most ancient types of linguography, but more and more topical today, is bilingual linguography. It is well known that the first dictionaries surviving until today were bilingual. Up to now, the humanity produced thousands of bilingual dictionaries, but this activity remains important and necessary (see $[2,3,4]$ and others).

Linguographic research is carried out at Kazan Federal University too, where Kazan Linguographic Fund is currently functioning, comprising a) dictionaries of the Russian and Tatar languages developed at University, and b) publications devoted to various issues of linguography $[5,6,7,8]$ and others.

\section{Methods}

The research is based on the methods of linguistic description, comparative method, contrastive method, and quantitative method.

\section{Results and discussion}

The object of research is linguistic informativity of the macrostructure of language reference books. The research material is bilingual 
(Russian-Tatar and Russian-Chinese) dictionaries of various types of the end of the $20^{\text {th }}$ - beginning of the $21^{\text {st }} \mathrm{cc}$.

In bilingual linguography, an important factor is the addressee of the dictionary. A language reference book having a single addressee is called monodirectional. This is characteristic for the analyzed Russian-Chinese dictionaries, which are aimed at the speakers of Chinese studying the Russian language. In these linguographic sources, the main components of the macrostructure are given in the Chinese language. However, for the practical purposes, most of the bilingual dictionaries have two addressees, thus being bidirectional.

Most of the language reference books analyzed in this paper are monoscopal, with one source language and one target language. For example, in the Tatar linguography of the second half of the $20^{\text {th }}-$ beginning of the $21^{\text {st }} \mathrm{cc}$, there are 189 bilingual dictionaries (137 of them Russian-Tatar), and 33 multilingual dictionaries [9].

In the recent years, it became popular to publish biscopal dictionaries, especially in the field of academic linguography.
95

By volume, the dictionaries are traditionally divided into brief (describing up to 8000 units), middlesized (from 8000 to 21000 units), and large. It is obvious that this division is conditional.

In this paper, we analyze both brief and large language reference books. Bilingual dictionaries are divided into general language (or general) dictionaries, comprising the whole corpus of the language, and special dictionaries. The special dictionaries traditionally include terminological (branch) reference books. By the data given in the bibliographic reference books [9], of the total number of Russian-Tatar dictionaries, 59\% (81 dictionaries) are terminological dictionaries.

Some lexicographers, in particular, V.P.Berkov, consider specialized dictionaries those describing non-terminological units: phraseological, quotation dictionaries [10].

Macrostructure of a language reference book comprises the following sections of a linguographic source: foreword, introduction, the list of abbreviations, appendices, selection and 
character of the vocabulary, the principle of arrangement of entries.

There are three types of arrangement of the language material in the analyzed linguographic sources:

A) initial-alphabetic (or direct alphabetic); most of the dictionaries are structured in this way;

B) alphabetic-cluster;

C) thematic (units are grouped by notions or meanings).

One of the key notions in of linguography, as well as the essential component of a language reference book, is the vocabulary. It comprises "all units forming the sphere of description of the dictionary", arranged by a certain system and serving as "entries into the dictionary" $[11,14,15]$.

In theoretical lexicography, vocabulary is understood as "a set of the units described in the dictionary, including title and in-entry units" [1:38].

Many lexicographers quite relevantly mark that the quality of vocabulary determines the quality of a dictionary. When developing vocabulary, a strict and systematic selection is necessary. One has to admit that in the modern linguography there is still no distinct objective criterion for
96

selecting words for a language reference book. When composing a vocabulary, subjective factors play a great role, as a result of which, the influence of idiolectal factor cannot be excluded. It is rather difficult to assign to a compiler, which words should be included into a vocabulary. However, there are a number of requirements to inclusion/exclusion of closed lexical groups, less frequent words, etc. (in more detail see [12,16, 17]).

The vocabulary mistakes and inaccuracies, revealed by the analysis of language reference books, can be classified as follows.

- Unjustified (or poorly justified) inclusion of unit into the vocabulary.

Such drawbacks are rather frequent in the analyzed linguographic sources. For example, in the foreword to the Chinese Linguistic-Culturological Dictionary (2005) the compilers mark that the dictionary comprises words reflecting the Russian culture, but doubts arise about inclusion of such words as кислород, негры and some others; or such units as аборт, ауди, порше, гомик, гомосексуализм, Шерлок Холмс, etc. in the Russian-Chinese 
Linguistic-Culturological Dictionary (2000).

It is doubtful whether the Russian-Tatar Dictionary of Technical Terms (2000) should contain such units as печень, психиатр, похмелье, and the Russian-Tatar Dictionary of Hygienic Terms (1999) - ветер мартеновский, газобетон.

Our analysis revealed the cases of inclusion into "The Russian-Chinese Learner's Dictionary" of the words uncommon (or lacking) in the Russian language; for example, частнопрактикующий - in Grand Thesaurus of the Russian Language [13] this unit is not found, while in the Russian National Corpus there are only 5 entries; магазин-квартира, спортсменка-балерина, спутникшпион, фотокосмический, химчисточный, хлопки-насмешки, хоббист - these collocations are not registered in any dictionary of the Russian language, nor in the Russian National Corpus.

In our opinion, in the learner's dictionaries it is inexpedient to register and describe the objects and phenomena, uncharacteristic for the relevant region; for example, маис, нарта, тутовник- in the "School Russian-Tatar Dictionary" (1989).

- The next group is unjustified absence of words in the dictionary.

When selecting the vocabulary of a logistic reference book, the content of appropriate linguographic classes are not always taken into account, sometimes even minimal, twocomponent ones (for example, of antonymic character). In the abovementioned "School Russian-Tatar Dictionary" there is no отчим, though there is мачеха, there are terms морфология, синтаксис, грамматика, орфография, омоним, синоним, but not фонетика, антоним.

In "The Russian-Tatar Pocket Dictionary" (1997) there is минус but not плюс, there is жених, but not невеста, there are курятина, телятина, свинина, but not говядина, баранина, there is библия, but not коран, there are албанеи, бельгиеи, болгарин, румын, but not татарин (!); there are западный, северный, южный, but not восточный.

“The Russian-Chinese learner's dictionary" (2010) gives as a separate entry двухсотьій, трехсотьій, пятисотый, шестисотыцй, семисотый, восьмисотый, but not 
четырехсотый, девятисотый; есть ярко-красный, but not other colors, like ярко-синий, ярко-зеленый. Ву the way, in the Russian National Corpus, яркозеленый has 62 entries, ярко-синий - 54 entries, while ярко-красный - only 3 entries.

Linguistic-culturological and linguistic-cultural dictionaries often lack the units inherent in the Russian culture. For example, the Chinese LinguisticCulturological Dictionary (2005) lacks words гречиха, морковь, пшеница, рожь, while there are каnуста, картофель (картошка), репа. In the theme "Musical instruments" there are words referring to national and international musical instruments балалайка, барабан, скрипка, etc., but such Russian folk musical instruments as баян, гармонь, гусли are not included. In the theme "Dwelling and place of residence" there is хрущеёвка, but not сталинка.

When analyzing the RussianChinese Linguistic-Cultural Dictionary (2000), one marks the absence of the entry П.И.Чайковский, while there are entries М.И.Глинка, С.В.Рахманинов, and А.К.Глазунов, the latter often called a creative successor of P.I. Tchaikovsky;
98 of the Russian artists of the $19^{\text {th }}-20^{\text {th }} \mathrm{cc}$, there are entries for И.Левитан, И.Репин, А.Саврасов, but surprisingly, in our opinion, no information about И.Айвазовский.

- The next group of drawbacks which one may notice is orthographic mistakes.

It is unacceptable for a dictionary, whatever type it belongs to, to have orthographic mistakes.

For example, "The Thematic Dictionary of French Borrowings in the Tatar Language" (2001) gives the following Russian words with erroneous spelling: aфёpa (orthoepic dictionaries give this form with a mark colloq., while literary norm is aфера), беф Строганофф (instead of бефстроганов), кашмир (instead of камемир), компромис (instead of компромисс).

"The Russian-Chinese Learner's Dictionary" (2010), pitifully, sometimes gives erroneous spelling of the element мини-: миниавтобус, миникомпьютер, миниюбка. Although the same reference book gives the correct spelling as well: мини-автомобиль, мини-грузовик, мини-книга, минифутбол еtс. 
In some bilingual dictionaries, the meaning of a word is demonstrated with visual means (pictures, photos, etc.). Sometimes, elements of an illustrative, or picture, dictionary are introduced into a usual language reference book, as in some cases only an illustration may vividly show how, for example, national costume looks, like косоворотка, чувяки еtc., or various household objects. For example, the monodirectional "Russian-Chinese Learner's Dictionary" quite logically gives pictures for such title units as домбра, плуг, собор, телега, тройка (in the meaning of "three horses in one relay'), ушанка, ушат. Tо use picture dictionaries in learning effectively, the visuals and the illustrative examples must be closely connected.

Sometimes a picture carries no sense, an illustration is incomprehensible: see pictures to the entries дуб, горох, земляника, клубника, кукушка, лён, малина, мандарин, овёс, стопка (in the meaning of 'a small wine glass'), фасоль, and many others.

Still more questions arise due to the lack of illustrations for some title units; for example, форменка, фуфайка, черепица, юрта, etc., while there are pictures for such units as: бокал, дорога, душ, жираф, лампа, лодка, лопата, полка, пылесос, плоскогубиы, попугай, рояль, сумка, тумбочка, etc.

In the bidirectional "RussianTatar Dictionary of Military Terms" (2000) pictures (photos, etc.) are given to the entries арбалет, бумеранг, копье, тесак, шашка and others, and are not given to the entries балиста, дага, кинжал, колчан, шиага; there is an illustration to the word $м е ч$, while there is no such unit in the dictionary.

\section{Summary}

Within our research, we analyzed one of the main components of a dictionary macrostructure - selection and character of the vocabulary, the principle of arrangement of dictionary entries.

During the research of the Russian-foreign language reference books, a number of mistakes and drawbacks referring to the vocabulary were revealed: a) unjustified inclusion of units into the vocabulary, b) unjustified absence of units in the vocabulary, c) orthographic mistakes, d) incorrect use 
of illustrative material (pictures, photos, etc.).

\section{Conclusions}

The paper presents the classification including various features of the existing bilingual dictionaries. Bilingual linguography comprises various types of language reference books.

Compiling the vocabulary, decision to include a specific unit into the dictionary is often made subjectively nowadays. Analysis of the bilingual dictionaries of various types reveals two most common groups of drawbacks unjustified inclusion of units into the vocabulary and unjustified absence of units in the vocabulary.

There is no single established opinion as to what information a learner's dictionary should include. When compiling a dictionary, each author (compiler) decides independently which zones to include/exclude, what words to take as the basis for vocabulary construction. It is important to remember that inclusion of specific information depends on the dictionary's addressee and purpose.
Linguographic

activity develops in this direction but there are still problems and tasks of varied character, which should be solved; among them: to develop new types of dictionaries, thus enriching the vocabulary base; to strive for greater objectivity when forming the vocabulary of a language reference book; to improve dictionaries' compilation, taking into account that its main objective is to satisfy the needs of the addressees.

\section{Acknowledgements}

The work is performed according to the Russian Government Program of Competitive Growth of Kazan Federal University.

\section{Bibliography}

Galiullin K.R., Karimullina R.N. Bases of linguography: tutorial. Kazan, 2017. $68 \mathrm{p}$.

Mugglestone L.The Oxford History of English. Oxford University Press, 2012.$624 \mathrm{p}$. 
Durkin Ph. (ed.). The Oxford Handbook of Lexicography. Oxford University Press, 2015. 736 p.

Xiangqing Wei et al. Lexicography in China (1978-2008). Beijing: The Commercial Press, 2014. VI + 445 p.

Ashrapova, A.H., Yusupova, A.S. Language and national identity in linguistic dictionaries (on material of bilingual dictionary of the Tatar language of the 19th century and the turn of the 20th century) // Journal of Language and Literature, Volume 6, Issue 1, 2015, pp. 318-321.

Galiullin K., Gorobets E., Martyanov D. Electronic terminological thesaurus in the information support of linguistics // SGEM $2014 \quad$ International Multidisciplinary Scientific Conferences on Social Sciences and Arts, $1-10$ September 2014, Section Education \& Educational Research, pp. 273-280.

Islamova Elvira A., Svetlana S. Safonova, Ramzia M. Bolgarova. Written records of the Kazan region of the XVI century: historical, lexicological and lexicographical aspects. Journal of
101

Language and Literature 2014; 5(4), pp. 321-324. DOI: 10.7813/j11.2014/5-4/68

Solnyshkina M., Gafiyatova E. Modern Forestry English: Macro- and Microstructure of Low Register Dictionary // Journal of Language and Literature, 2014, 5 (4), pp. 220-224.

Karimullina R.N. (comp.), Galiullin K.R. (ed.). Tatar lingougraphy: dictionaries of the Tatar language of 1951-2008: bibliographic reference book. Kazan, 2011. 536 p.

Berkov V.P. Bilingual lexicography: tutorial. Moscow: AST: Astrel, 2004. $236 \mathrm{p}$.

Baranov A.N. Introduction to applied linguistics: tutorial. Moscow: Editorial URSS, 2001. 360 p.

Galiullin K.R., Karimullina G.N., Karimullina R.N. Linguographic classes in language reference books of the $21^{\text {st }}$ century. In: K.R. Galiullin, E.A. Gorobets, A.A. Nikolaev (eds.). Works and materials of International Conference "I.A. Baudouin de Courtenay and the world linguistics", $5^{\text {th }}$ 
Baudouin Readings (Kazan Federal University, 12-15 October 2015). In 2 vol. Kazan: Kazan Federal University, 2015. Vol. 2. Pp.64-66.

Kuznetsov S.A. (ed.). Grand Thesaurus of the Russian Language. Saint Petersburg: Norint. 1998.

Kord, H., Noushiravani, Y., Bahadori, M. D., \& Jahantigh, M. (2017). Review and Analysis of Telework Perspective in the Administrative Systems. Dutch Journal of Finance and Management, $1(2)$, 44.

https://doi.org/10.29333/djfm/5820

Mazurova, E. (2017). Exploratory Analysis of the Factors Affecting Consumer Choice in E-Commerce: Conjoint Analysis. Journal of Information Systems Engineering \& $\begin{array}{lll}\text { Management, } & 2(2), & 12 .\end{array}$ https://doi.org/10.20897/jisem.201712

Sears, R. (2018). The Implications of a Pacing Guide on the Development of Students Ability to Prove in Geometry. International Electronic Journal of Mathematics Education, 13(3), 171-183. https://doi.org/10.12973/iejme/3835
Shatilova, L. M., Borisova, V. V., \& Kasatkina, O. A. (2018). Representation of the linguistic and cultural concept "lie" in the French and Russian language picture of the world. Opción, 34(85-2), 257-276 